\title{
Frequency of the $L R R K 2$ G2019S mutation in Italian patients affected by Parkinson's disease
}

\author{
Tiziana Squillaro $\cdot$ Franca Cambi $\cdot$ Giuseppe Ciacci $\cdot$ Simone Rossi $\cdot$ \\ Monica Ulivelli · Alessandro Malandrini · Maria Antonietta Mencarelli · \\ Francesca Mari · Alessandra Renieri · Francesca Ariani
}

Received: 31 July 2006/ Accepted: 13 December 2006/Published online: 18 January 2007

(C) The Japan Society of Human Genetics and Springer 2007

\begin{abstract}
Mutations in the gene Leucine-Rich Repeat Kinase 2 (LRRK2) have been identified in both dominant and sporadic cases affected by Parkinson's disease (PD). The LRRK2 G2019S mutation (c.6055G $>\mathrm{A})$ is the most frequent substitution in Caucasians, accounting for approximately 5-6\% of familial and $0.5-2.0 \%$ of apparently sporadic PD cases. We investigated the frequency of the LRRK2 G2019S mutation in 98 unrelated Italian PD patients, including 12 probands belonging to families compatible with autosomal dominant inheritance $(12 \%)$ and 86 sporadic cases $(88 \%)$. We detected the G2019S mutation in one sporadic female patient $(1.2 \%)$. These results confirm that the G2019S mutation is a relevant cause of sporadic PD cases in the Italian population and stress the importance of performing this genetic test, which has important implications for genetic counselling.
\end{abstract}

T. Squillaro - M. A. Mencarelli · F. Mari ·

A. Renieri $(\bowtie) \cdot$ F. Ariani

Medical Genetics, Molecular Biology Department,

University of Siena, V. Le Bracci, 53100 Siena, Italy

e-mail: renieri@unisi.it

F. Cambi

Department of Neurology, University of Kentucky,

Lexington, KY 40536-0284, USA

G. Ciacci

Neurology Unit, Azienda Ospedaliera Senese, Siena, Italy

S. Rossi · M. Ulivelli

Department of Neurosciences, Neurology Unit,

University of Siena, Siena, Italy

A. Malandrini

Department of Neurological and Behavioural Sciences,

University of Siena, Siena, Italy
Keywords Parkinson's disease · PD - LRRK2 .

G2019S · Penetrance · Familial cases · Sporadic cases

Parkinson's disease (PD; MIM 168600) is the second most common neurodegenerative disorder after Alzheimer's disease, affecting more than $1 \%$ of individuals aged 55 years (Polymeropoulos et al. 1996). The disease is clinically defined by the association of bradykinesia, resting tremor, muscular rigidity and postural instability (Gelb et al. 1999). Neuropathological features include loss of dopaminergic neurones in the substantia nigra-pars compacta and other brain regions, with formation of ubiquitin-containing inclusions (Lewy bodies) in the surviving neurones (Forno 1996).

The cause of the disease remains unknown in most patients, but a positive family history of PD is found in $\sim 15-25 \%$ of cases, and mutations in five genes have been firmly implicated in the aetiology of these rare inherited forms of the disease (Polymeropoulos et al. 1997; Kitada et al. 1998; Bonifati et al. 2003; Valente et al. 2004; Zimprich et al. 2004).

An autosomal dominant form of parkinsonism (PARK8) was first mapped to chromosome 12 in a Japanese family (Funayama et al. 2002). This linkage was successively confirmed in Caucasian families and mutations in the gene Leucine-Rich Repeat Kinase 2 (LRRK2) have been identified in PARK8-linked families (Paisan-Ruiz et al. 2004; Zimprich et al. 2004). The $L R R K 2$ gene has 51 exons and encodes a protein of 2,527 amino acids. The LRRK2 protein has unknown function, although there are five predicted functional domains: a leucine-rich repeat, a Roc (Ras guanosine triphosphatase) domain, a COR (C-terminal 
of Roc) domain, a WD40 (beta-tranducin repeats) domain and a tyrosine kinase catalytic domain (PaisanRuiz et al. 2004; Zimprich et al. 2004).

Until now, several different missense mutations have been identified in the LRRK2 gene (Zimprich et al. 2004; Aasly et al. 2005; Hernandez et al. 2005; Kachergus et al. 2005; Khan et al. 2005; Mata et al. 2005; Paisan-Ruiz et al. 2005; Zabetian et al. 2005). In particular, the G2019S substitution in exon 41 accounts for approximately $5-6 \%$ of familial and $0.5-2 \%$ of apparently sporadic PD cases in populations of European origin (Di Fonzo et al. 2005; Farrer et al. 2005; Gilks et al. 2005; Kachergus et al. 2005; Nichols et al. 2005; Gaig et al. 2006). Furthermore, recent studies have indicated an extremely high prevalence of the G2019S mutation in Ashkenazi Jews (13.3\% sporadic; 29.7\% familial) and North African Arabs (40.8\% sporadic; 37.0 familial) affected by PD (Lesage et al. 2006; Ozelius et al. 2006). Kachergus et al. (2005) reported that G2019S penetrance is age-dependent, increasing from $17 \%$ at age 50 to $85 \%$ at age 70 years. However, very recent studies found that G2019S penetrance could be lower than previously reported (S. Goldwurm, personal communication). In the Italian population, the prevalence of the G2019S mutation is $5.1 \%$ among PD familial cases and $0.9 \%$ among sporadic patients (Goldwurm et al. 2005). The G2019S mutation alters a critical residue in the kinase domain of the protein, and it has been postulated that the mutation may have an activating effect on LRKK2 kinase activity (Kachergus et al. 2005). A mutation linked to a "gain of function" of the resulting protein is also compatible with the dominant mode of inheritance of the disease observed in family studies.

The aim of this study was to determine the frequency of the LRRK2 G2019S mutation in Italian patients with idiopathic PD who have been referred to our Medical Genetics Unit by neurologists from the University Hospital of Siena. We performed the analysis of the LRRK2 G2019S mutation in 98 unrelated PD patients, originating mostly from the Tuscan region, central Italy. In this group of patients, 12 belong to families compatible with autosomal dominant inheritance $(12 \%)$ and 86 are sporadic cases $(88 \%)$. Among familial cases, 6 are early onset (mean age at onset: $41.2 \pm 4.4$ years) and 6 late onset cases (mean age at onset: $62.2 \pm 6.8$ years). The sporadic group includes 24 early onset (mean age at onset: $40.7 \pm 8$ years) and 62 late onset patients (mean age at onset: $62.6 \pm 6.7$ years).

DNA was extracted using standard methods (Sambrook et al. 1989). Mutation analysis was performed by denaturing high performance liquid chromatography
(DHPLC) using Transgenomic WAVE (Transgenomic, San Jose, CA). For PCR, we used the following primers: LRRK2_41_F: 5'-ATGCTTGACATAGTGG ACA-3' and LRRK2_41_R: 5'-AGGTCAGTGGTTA TCCATC-3' (amplicon size: $316 \mathrm{bp}$ ). The optimal column temperature for fragments analysis $\left(59^{\circ} \mathrm{C}\right)$ was calculated using WaveMarker Software (Transgenomic). Direct sequencing of the purified PCR products was carried out in both directions on an ABI310 Automated Sequencer.

We detected the LRRK2 G2019S mutation in one sporadic case $(1.2 \%, 1 / 86$ sporadic patients). The patient is a 53-year-old female who developed PD symptoms at the age of 47 years. The disease started with bradykinesia, severe dyskinesias and rigidity. At present, psychiatric disturbances are not present and the patient is treated with levodopa. Her parents are still alive, are 78 and 75 years old, and a recent neurological examination did not show any sign of PD. DNA from the parents is not available for genetic testing. The proband has a healthy 16-year-old son.

These results confirm previous studies that demonstrated a frequency of about 1\% for the G2019S mutation in sporadic cases with idiopathic PD in the Italian population (Goldwurm et al. 2005). On the other hand, the mutation was not detected in any of the 12 familial PD probands. This result is not unexpected since the LRRK2 G2019S mutation is reported in about $5 \%$ of PD familial cases (Goldwurm et al. 2005).

Concerning disease onset, previous studies reported the G2019S mutation prevalently associated with late onset PD ( $>50$ years) (Kachergus et al. 2005; Infante et al. 2006). In addition, Goldwurm et al. (2005) observed that the average disease onset of females carrying the G2019S mutation is about 10 years earlier than that of males (47.1 years vs 56.5 years). Our female patient developed PD symptoms at the age of 47 years and this is in accordance with previous data. However, a larger number of mutated cases is needed to firmly confirm the age of disease onset associated with the G2019S mutation.

Since genetic predisposition is important in the pathogenesis of PD, and the LRRK2 G2019S mutation contributes to a significant percentage of cases, screening for this substitution may become a key component of genetic testing for PD in the near future. As already underlined in previous studies, such genetic tests should also be extended to sporadic cases. In fact, the late onset of PD in G2019S mutated patients together with the reduced penetrance of this mutation, can sometimes mask its familial occurrence.

The identification of a frequent genetic determinant of PD also has important implications for genetic 
counselling. The lifetime risk of developing PD for the son of the patient described here shifts from $2 \%$, reported for first-degree relatives of an affected individual, to about $42.5 \%$, considering the penetrance of the mutation (Marder et al. 1996; Kachergus et al. 2005). Analysis of the G2019S LRRK2 mutation in large cohorts of PD cases is necessary to better assess penetrance rate prior to offering presymptomatic tests to relatives.

\section{References}

Aasly JO, Toft M, Fernandez-Mata I, Kachergus J, Hulihan M, White LR, Farrer M (2005) Clinical features of LRRK2associated Parkinson's disease in central Norway. Ann Neurol 57:762-765

Bonifati V, Rizzu P, van Baren MJ, Schaap O, Breedveld GJ, Krieger E, Dekker MC, Squitieri F, Ibanez P, Joosse M, van Dongen JW, Vanacore N, van Swieten JC, Brice A, Meco G, van Duijn CM, Oostra BA, Heutink P (2003) Mutations in the DJ-1 gene associated with autosomal recessive earlyonset parkinsonism. Science 299:256-259

Di Fonzo A, Rohe CF, Ferreira J, Chien HF, Vacca L, Stocchi F, Guedes L, Fabrizio E, Manfredi M, Vanacore N, Goldwurm S, Breedveld G, Sampaio C, Meco G, Barbosa E, Oostra BA, Bonifati V (2005) A frequent LRRK2 gene mutation associated with autosomal dominant Parkinson's disease. Lancet 365:412-415

Farrer M, Stone J, Mata IF, Lincoln S, Kachergus J, Hulihan M, Strain KJ, Maraganore DM (2005) LRRK2 mutations in Parkinson disease. Neurology 65:738-740

Forno LS (1996) Neuropathology of Parkinson's disease. J Neuropathol Exp Neurol 55:259-272

Funayama M, Hasegawa K, Kowa H, Saito M, Tsuji S, Obata F (2002) A new locus for Parkinson's disease (PARK8) maps to chromosome 12p11.2-q13.1. Ann Neurol 51:296-301

Gaig C, Ezquerra M, Marti MJ, Munoz E, Valldeoriola F, Tolosa E (2006) LRRK2 mutations in Spanish patients with Parkinson disease: frequency, clinical features, and incomplete penetrance. Arch Neurol 63:377-382

Gelb DJ, Oliver E, Gilman S (1999) Diagnostic criteria for Parkinson disease. Arch Neurol 56:33-39

Gilks WP, Abou-Sleiman PM, Gandhi S, Jain S, Singleton A, Lees AJ, Shaw K, Bhatia KP, Bonifati V, Quinn NP, Lynch J, Healy DG, Holton JL, Revesz T, Wood NW (2005) A common LRRK2 mutation in idiopathic Parkinson's disease. Lancet 365:415-416

Goldwurm S, Di Fonzo A, Simons EJ, Rohe CF, Zini M, Canesi M, Tesei S et al (2005) The G6055A (G2019S) mutation in LRRK2 is frequent in both early and late onset Parkinson's disease and originates from a common ancestor. J Med Genet 42:e65

Hernandez DG, Paisan-Ruiz C, McInerney-Leo A, Jain S, MeyerLindenberg A, Evans EW, Berman KF, Johnson J, Auburger G, Schaffer AA, Lopez GJ, Nussbaum RL, Singleton AB (2005) Clinical and positron emission tomography of Parkinson's disease caused by LRRK2. Ann Neurol 57:453-456

Infante J, Rodriguez E, Combarros O, Mateo I, Fontalba A, Pascual J, Oterino A, Polo JM, Leno C, Berciano J (2006) LRRK2 G2019S is a common mutation in Spanish patients with late-onset Parkinson's disease. Neurosci Lett 395:224226
Kachergus J, Mata IF, Hulihan M, Taylor JP, Lincoln S, Aasly J, Gibson JM, Ross OA, Lynch T, Wiley J, Payami H, Nutt J, Maraganore DM, Czyzewski K, Styczynska M, Wszolek ZK, Farrer MJ, Toft M (2005) Identification of a novel LRRK2 mutation linked to autosomal dominant parkinsonism: evidence of a common founder across European populations. Am J Hum Genet 76:672-680

Khan NL, Jain S, Lynch JM, Pavese N, Abou-Sleiman P, Holton JL, Healy DG et al (2005) Mutations in the gene LRRK2 encoding dardarin (PARK8) cause familial Parkinson's disease: clinical, pathological, olfactory and functional imaging and genetic data. Brain 128:2786-2796

Kitada T, Asakawa S, Hattori N, Matsumine H, Yamamura Y, Minoshima S, Yokochi M, Mizuno Y, Shimizu N (1998) Mutations in the parkin gene cause autosomal recessive juvenile parkinsonism. Nature 392:605-608

Lesage S, Durr A, Tazir M, Lohmann E, Leutenegger AL, Janin S, Pollak P, Brice A (2006) LRRK2 G2019S as a cause of Parkinson's disease in North African Arabs. N Engl J Med 354:422-423

Marder K, Tang MX, Mejia H, Alfaro B, Cote L, Louis E, Groves J, Mayeux R (1996) Risk of Parkinson's disease among first-degree relatives: a community-based study. Neurology 47:155-160

Mata IF, Kachergus JM, Taylor JP, Lincoln S, Aasly J, Lynch T, Hulihan MM, Cobb SA, Wu RM, Lu CS, Lahoz C, Wszolek ZK, Farrer MJ (2005) Lrrk2 pathogenic substitutions in Parkinson's disease. Neurogenetics 6:171177

Nichols WC, Pankratz N, Hernandez D, Paisan-Ruiz C, Jain S, Halter CA, Michaels VE, Reed T, Rudolph A, Shults CW, Singleton A, Foroud T (2005) Genetic screening for a single common LRRK2 mutation in familial Parkinson's disease. Lancet 365:410-412

Ozelius LJ, Senthil G, Saunders-Pullman R, Ohmann E, Deligtisch A, Tagliati M, Hunt AL, Klein C, Henick B, Hailpern SM, Lipton RB, Soto-Valencia J, Risch N, Bressman SB (2006) LRRK2 G2019S as a cause of Parkinson's disease in Ashkenazi Jews. N Engl J Med 354:424-425

Paisan-Ruiz C, Jain S, Evans EW, Gilks WP, Simon J, van der Brug M, Lopez de Munain A, Aparicio S, Gil AM, Khan N, Johnson J, Martinez JR, Nicholl D, Carrera IM, Pena AS, de Silva R, Lees A, Marti-Masso JF, Perez-Tur J, Wood NW, Singleton AB (2004) Cloning of the gene containing mutations that cause PARK8-linked Parkinson's disease. Neuron 44:595-600

Paisan-Ruiz C, Lang AE, Kawarai T, Sato C, Salehi-Rad S, Fisman GK, Al-Khairallah T, St George-Hyslop P, Singleton A, Rogaeva E (2005) LRRK2 gene in Parkinson disease: mutation analysis and case control association study. Neurology 65:696-700

Polymeropoulos MH, Higgins JJ, Golbe LI, Johnson WG, Ide SE, Di Iorio G, Sanges G, Stenroos ES, Pho LT, Schaffer AA, Lazzarini AM, Nussbaum RL, Duvoisin RC (1996) Mapping of a gene for Parkinson's disease to chromosome 4q21-q23. Science 274:1197-1199

Polymeropoulos MH, Lavedan C, Leroy E, Ide SE, Dehejia A, Dutra A, Pike B, Root H, Rubenstein J, Boyer R, Stenroos ES, Chandrasekharappa S, Athanassiadou A, Papapetropoulos T, Johnson WG, Lazzarini AM, Duvoisin RC, Di Iorio G, Golbe LI, Nussbaum RL (1997) Mutation in the alphasynuclein gene identified in families with Parkinson's disease. Science 276:2045-2047

Sambrook J, Fritsch E, Maniatis T (1989) Molecular cloning: a laboratory manual, 2nd edn. Cold Spring Harbour Laboratory Press, NY 
Valente EM, Abou-Sleiman PM, Caputo V, Muqit MM, Harvey K, Gispert S, Ali Z, Del Turco D, Bentivoglio AR, Healy DG, Albanese A, Nussbaum R, Gonzalez-Maldonado R, Deller T, Salvi S, Cortelli P, Gilks WP, Latchman DS, Harvey RJ, Dallapiccola B, Auburger G, Wood NW (2004) Hereditary early-onset Parkinson's disease caused by mutations in PINK1. Science 304:1158-1160

Zabetian CP, Samii A, Mosley AD, Roberts JW, Leis BC, Yearout D, Raskind WH, Griffith A (2005) A clinic-based study of the LRRK2 gene in Parkinson disease yields new mutations. Neurology 65:741-744

Zimprich A, Biskup S, Leitner P, Lichtner P, Farrer M, Lincoln S, Kachergus J, Hulihan M, Uitti RJ, Calne DB, Stoessl AJ, Pfeiffer RF, Patenge N, Carbajal IC, Vieregge P, Asmus F, Muller-Myhsok B, Dickson DW, Meitinger T, Strom TM, Wszolek ZK, Gasser T (2004) Mutations in LRRK2 cause autosomal-dominant parkinsonism with pleomorphic pathology. Neuron 44:601-607 